\title{
GLOBAL EDUCATION, RESEARCH AND TECHNOLOGY FOR SUSTAINABLE DEVELOPMENT
}

\author{
Forgive Kwadamah ${ }^{1}$, Francis Pol C. Lim ${ }^{2}$, Ebenezer Dzinpa Effisah ${ }^{3}$ and Siddique \\ Abdul-Samad ${ }^{4}$ \\ ${ }^{1}$ College of Distance Education, Zenith University College Centre, University of \\ Cape Coast, Ghana \\ ${ }^{2}$ SMC University, Bahnhofstrasse 20, $6300 \mathrm{Zug}$, Switzerland \\ ${ }^{3}$ College of Distance Education, Papafio Hills, University of Cape Coat, Ghana \\ ${ }^{4}$ Human Resource Directorate, University of Professional Studies, Ghana \\ ${ }^{1}$ forgivekwadamah@yahoo.com, ${ }^{2}$ limfrancispol19@ gmail.com, \\ 3eefissah@ucc.edu.gh, ${ }^{4}$ siddiquesamad3@gmail.com
}

\begin{abstract}
This paper reviews significant issues concerning the evolution of global education, research and technology for sustainable development. The paper recognises the strides education has made in terms of socio-economic development, politics, communication and globalisation. The paper also touches on the idealness of global education and its various dimensions. This paper acknowledges that a synergy between technology and education can break the chain of poverty worldwide and engender empowerment. This paper brilliantly outlines the manner in which contemporary technology is gradually rendering the traditional classroom extinct in favour of virtual classroom. The paper finally recommends that all educational authorities, across the globe, embrace educational technology for prompt and effective impartation of knowledge for sustainable socio-economic development.
\end{abstract}

Keywords - Global education, research, technology, socio-economic development, sustainable development

\section{INTRODUCTION}

Education is a source of improvement in the life of the underprivileged people. It one of the greatest devices used in liberating people from socio-economic hardships and inequity (Commonwealth of Australia, 2008). Through the liberation from socioeconomic hardships and inequity, the individual develops new perceptions about the world. The knowledge and expertise people acquire unlock fresh opinions concerning the globe and produce options and the nerve to assume opportunities to enhance well-being, nourishment, earnings and living standards and participation in decision making (Commonwealth of Australia, 2008; Osler, 2002). The whole world has become a single community known as the global village. This is due to the fact that the global neighborhood is a network of different cultures, economics and politics, improved communication and tourism and a common surrounding (Commonwealth of Australia, 2008). Global education is a means for the consolidation of geographically remote places in the world. Global education, as a tool, puts premium on cohesion and interaction of

Received: August 10, 2019

Reviewed: October 10, 2019

Accepted: October 29, 2019 
humanity, improving awareness of ego and admiration of cultural differences, declaration of social justice and human rights, fostering harmony and actions for supportable future in unequal periods and locations (Commonwealth of Australia, 2008).

Global education is concerned about the impartation of knowledge and skills about the world to all ages across the world. Global education refers to the system of developing human capital or potential via which universal knowledge, which consists of many attempts to make known transnational topics in the classroom environment (Global Education- Review of Literature, n.d.; Osler, 2002). Educationists, all over the world, attempted to give global education a definite definition. They wanted to define global education in a manner that would make clear specific collection of subject matters, problems, observations and academic practices which provide panacea to the major issues of the ever-increasing globalised universe (Global Education- Review of Literature, n.d. Osler, 2002). In pursuit of global education, some advanced countries had initiated the development of their curricular from the international perspective. In their attempt to embrace global education, educational institutions in Canada, the United States of America and the United Kingdom had initiated the development of unconventional curricula about offshore issues in the year 1910 (Global Education- Review of Literature, n.d.). Non-governmental organizations played pivotal roles in the amalgamation of the study of both local and international subject matters. The New Education Fellowship and the Workers' Educational Association was one of the organizations which made the necessary attempt to connect the study of international issues to the campaign for world peace, learner-centred models of instruction and education for international comprehension (Global Education - Review of Literature, n.d.; Pike \& Selby, 2000). In this era, Social Studies emerged in addition to History and Geography, and were taught about other nations as a separate knowledge. These other methods of teaching about foreign issues were integrated into the mandates of many of the United Nations' subbodies (Global Education - Review of Literature, n.d.). The United Nations Educational, Scientific and Cultural Organization (UNESCO) and the International Bureau of Education (IBE) of the United Nations initiated their support for a system of teaching that fostered world harmony through international agreement and later endorsed the Universal Declaration of Human Rights. Under the "Education for All" programs driven by UNESCO, most countries have pledged to achieve universal enrollment in primary education by the year 2015, which is compulsory in many countries. This gives an opportunity to every child to pass through the educational system up to the secondary level, with the aim of making sure that, at least, every child is able to read and write on a global scale.

The difference between primary and secondary education is somewhat arbitrary. A class of scholars initiated the organisation of these alternative pedagogical methods to teaching about international matters in the 1970s and early 1980s. However, children were seen to be hardly learning how to live in a progressively autonomous world (Hanvey, 1976). It was vehemently contended that the formal curriculum concentrated on other peoples and their cultures, impressing upon the children the doctrine of "them/us". Anderson and Harvey regarded the prominence given international issues as suppressing active citizen participation in domestic affairs, forgetting that the child needs to be open-minded toward the world. The researchers were trying to advocate for an inward-looking type of education for children, oblivious of the fact that the world, which is a global village, is cosmopolitan in nature. Anderson and Harvey started connecting the object of the 'Development Education' and 'Peace Education" activities with the UN's 'Education for International Understanding and Human Rights' efforts with the gradual concept of child-centred and affective learning. The two scholars, in addition, created a linkage between local educational activities for civil rights and cultural diversity, and embraced the flourishing endeavours of the new human rights education actions (Fujikane, 2003). It can be said with emphasis that Anderson and 
Harvey have contradicted themselves by linking multiculturalism, which is an aspect of globalism, to domestic education. Later, matters of environmental sustainability were added to those of social equity and multicultural awareness within social setups (Pike \& Selby, 2000; Richardson, Blandes, Kumano \& Karaki, 2003; Osler, 2002). This implies that education, in itself, is a multidisciplinary process which knows no geographical boundaries. Progressively, global education seems to be an area or subject matter in national curricula, frequently varied as 'Global Citizenship Education' to elaborate the philosophy of active learning and public arrangements that underscore the work of global education advocates (Rauner, 1998). Today, the term global education and its related educational movements appear increasingly in formal curricula around the world, with technology being the backbone of its accurate and timely delivery.

International matters were given prominence in the educational curricula. The status quo of teaching about transnational issues, nevertheless, remained the same just after the World War II. Public school curricula were designed to focus, principally, national attention on shaping children's behaviour to fit membership in national citizenry and expose them to only the high politics of global issues (Rauner, 1998). The World War II provided the foundation for the methods education in the 1940s. These traditional nationalistic approaches were underpinned by the Cold War apprehensions (Rauner, 1998).

\section{IS GLOBAL EDUCATION IDEAL?}

Global educators are not certain about the form global education should assume. Some scholars have theorised global education as a continuum that starts with the usual practices for imparting knowledge about world issues and world cultures and continues towards an intensifying form of global education whose focal point is not just on content knowledge but on the attitudes, values and behaviours required for the membership of global society, and at the extreme terminal of this continuum would be a dedication to global social justice, universal rights and ecological sustainability (Richardson et al., 2003; Global Education - Review of Literature, (n.d.).

The essence of global education ideology has been rendered controversial. It should be known that the global education idea is both tremendously broad in scope and awfully difficult to put into practice (Richardson et al., 2003; Global Education - Review of Literature, n.d), the perfect vision of global education proposed by its advocates has brought up several questions and worries. This presupposes that global educators have different views about the value of global education. There are three clear viewpoints on this issue. First, global educators have lackadaisical attitude toward the main aim of global education. The fact is that global educators are usually not much enthused about attempts to connect learning to the advancement of supranational competitiveness (Richardson, 2004). Second, many are those who have placed economic premium on education. Several parents and experts continue to think that education is justifiably concerned with greater economic achievement for both individuals and nations (Global Education - Review of Literature, n.d., Richardson, 2004). This assertion has a partial view of the importance of education because the focus of education must be the comprehensive development of the individual - head, heart and hand. Third, the belief in global citizenship was doubted. The perception of global citizenship is also debatable when defined as confidence in the requirement for a global political authority something a lot of people are skeptical about (Heater, 1996). In a similar vein, some people disagreed with Oxfam's definition of global education as something that is significantly centred on moral outrage and logic of social discrimination (Oxfam, 1997). Global education can only be ideal if it is devoid of social discrimination and racism. It is believed from research that teachers will avoid open derogatory 
discussions of matters which breed tension - often departing from the 'thin' form of global education which basically exposes students to other beliefs and peoples (Bickmore, 2005).

\section{GLOBAL EDUCATION AND RESEARCH NEED TECHNOLOGY FOR SUSTAINABLE DEVELOPMENT}

Technology is a tool of human capital development and transformation. Technology is a modifier in the area of education - a game-changer that is urgently required to both augment success for all and improve equality for children and societies who have been traditionally underprivileged (Duncan, 2012). This implies that technology, in conjunction with education, can tackle poverty and bring the down-trodden to the limelight. Through televisions and modern cell phones, many unheard-of communities and cultures have been showcased to the rest of the world (Duncan, 2012). Technology has introduced more efficiency in present-day education. Technology grants students the chance to carry out their work at their own speed, follow their own hobby and desires, and offers access to plenty of information via a cell phone than one could discover an entire orthodox library (Duncan, 2012).

Technology has almost wiped out the traditional system of teaching and learning. Technology is gradually taking the place of the writing materials, the course books, the chalk board and the globe in the corner of the conventional classroom (Duncan, 2012). This presupposes that, very soon, the impartation of knowledge will take place in virtual classrooms, after which examinations done using pen and paper will be nonexistent. The fact is that technology has created the novel platform for a flexible and smooth teaching and learning process in the $21^{\text {st }}$ Century (Duncan, 2012).

The present-day novel classroom created by technology requires dynamic teachers who embrace technology in education. Luckily, broad-minded tutors in school systems all over America are discovering innovative and novel approach to technology usage in the classroom setup (Duncan, 2012). Technology has demonstrated that it is an influential factor in the creation of equal opportunity for all people in education. It is an effective force in the provision of uniform opportunity of education, and that passion to grant every young person, irrespective of origin or social class, access to first-class education - it is the thrust behind the efforts of some public officials to declare education a universal right (Duncan, 2012). The provision of laptops smart phones and iPhones to those do not have them will bridge the gap in educational equity.

Technology is on the verge of disbanding the caste in society in the world. It has outshone poverty, race and economics to grant impetus to the lives of the masses, in that more than two billion people have access to the internet and five billion use mobile phones in the world - technology is a liberator (Kelly, 2013). Technology has, over the years, been regarded as an effective device for advancement in all walks of life. Gradually, technology has become a development cutting-edge tool utilised in the world toward the achievement child-centred goals in global education, livelihoods and health (Kelly, 2013). It must now be accepted that technology, from all indications, is a true transformer across the globe. Initially, this technology was not meant to be a development tool; hitherto, it has turned out to be one of the most powerful instruments for change in all directions (Kelly, n.d., 2013). Children embrace new things easily so the adoption of technology in education would not pose any challenge to them. Children are absorbers of fresh technologies and surely the ability for technology and digital media to be a booster of innovation, education and change is simply the introduction to be achieved (Kelly, n.d). Technology does not only improve the mode of delivery of education to the youth but spreads important information to recipients at various spots on the globe. Red Cross, in collaboration with communication providers, created a location-targeted SMS system named Trilogy Emergency Relief Application (TERA) in Sierra Leone, which has the 
ability to deliver messages to 36,000 recipients within an hour at the click of a button (Cross, 2013). This implies that educational technology is not only child-inclined but aimed at all ages. Getting access to mobile phones and the internet can disband the sense of discrimination, against girls, equip them with confidence, good language and high literacy skills and improve their access to jobs which were hitherto the preserve of boys (Cross, 2013). Corporate social responsibility can bridge the gap of inequality between boys and girls in terms of employment. Therefore, corporate sector can assist girls to develop these attributes through organising ICT programmes, recruiting and hiring females for technology-related jobs (Ratfree, 2013). This suggests that technology has the ability break the shackles of poverty in society if it is appropriately used.

\section{RECOMMENDATION AND CONCLUSIONS}

This article recommends that educational authorities all over the world should adopt modern technology in pedagogy, and place little premium on the physical classroom and face-to-face approach to impartation of knowledge so that society can realise efficiency in educational delivery. This efficiency in pedagogy can only be achieved on condition that prominence is given to the virtual classroom. Because formal educational systems that assist educators incorporate ICT into shared teaching methods can aid augment learning results and impart the knowledge of ' $21^{\text {st }}$ Century Skills', to be precise, the use of technology, problem-solving, teamwork and self-motivation (Ratfree, 2013).

The paper concludes that the system of global education needs modern information communication technology for prompt and accurate delivery of educational information. The use of modern information communication technology in educational delivery can break the barrier created by geographical distance. The paper also admits that distance is no more a barrier to learning about the culture and society of other peoples, and global education can only be a reality if the syndrome of discrimination and racism is disbanded. It is an undeniable fact, to state, that technology has comprehensively changed the traditional classroom setup into a modern platform for effective teaching and learning across the world (Duncan, 2012). The game-changing ability of technology has almost rendered the age-old modus operandi of educational delivery a bygone. The face of educational delivery has changed dramatically, in that technology has almost taken the place of the writing materials, the course books, the chalkboard and the globe in the corner of the classroom (Duncan, 2012). In times to come, the orthodox method of teaching and learning will become extinct; hence this phenomenon augurs well for the sustainable socio-economic development of every nation.

\section{REFERENCES}

[1] Bickmore, K. (2005). Teacher development for conflict participation: Facilitating learning. InternationalJournal of Citizenship and Teacher Education, 1(2). Retrieved from: http://www.citized.info

[2] Cross, M. (2013). How technological innovation can protect children emergency zones. The Guardian. Retrieved from: https://www.the guardian.com/sustainable-business/technology-empower-childrendevelopment-countries.

[3] Commonwealth of Australia (2008). Global perspectives: A framework for global education in Australia schools. Australia: Education Services Australia.

[4] Duncan, A. (2012). The new platform for learning. US Department of Education. Retrieved from: https://www.ed.gov/news/speeches/new-platform-learning.

[5] Fujikane, H. (2003). Approaches to global education in the United States, the United Kingdom and Japan. International Review of Education, 49(1-2), 133-152.

[6] Global Education-Review of Literature (n.d.). Charting global education in Canada's elementary schools. Retrievedfrom: Global Educ, Research \& Technology.docx

[7] Hanvey, R. (1976). An attainable global perspective. New York: Center for Global Perspective.

[8] Heater, D. (1996). World citizenship and government: Cosmopolitan ideas in the history of Western political thought. London: Macmillan. 
[9] Kelly, A. (2013). A digital world: What impact the technology has on children? The Guardian. Retrieved from: https://www.the guardian.com/sustainable-business/technology-empower-children-developmentcountries.

[10] Kenny, C. (n.d.). Technology can empower children in developing countries-if it's done right. The Guardian. Retrieved from: https://www.the guardian.com/sustainable-business/technology-empowerchildren-development-countries.

[11] Osler, A. (2002). Educating for global citizenship in a changing world. Retrieved from: https://www.oise.utoronto.ca/cidec/UserFiles/File/Research/UNICEF_Study/UNICEF_chap2.pdf

[12] Oxfam, GB (1997). Education for global citizenship. Retrieved from: Global Educ, Research \& Technology.docx

[13] Pike, G. \& Selby, D. (2000). Global Education: Relevant learning for the twenty-first century. Retrieved from: Global Educ, Research \& Technology.docx

[14] Raftree, L. (2013). Empowering girls through technology: What's the role for business? The Guardian. Retrieved from: https://www.the guardian.com/sustainable-business/technology-empower-childrendevelopment-countries.

[15] Rauner, B. (1998). Global Education - Review of Literature (n.d.). Charting global education in Canada's elementary schools. Retrieved from: Global Educ, Research \& Technology.docx

[16] Richardson, G, H., Blades, D., Kumano, Y. \& Karaki, K. (2003). Charting global education in Canada's elementary schools. Retrieved from: Global Educ, Research \& Technology.docx 